\title{
Uudet kysymykset
}

Tutkimus alkaa hyvistä kysymyksistä: Huomiosta, että olemassa olevat selitysmallit ja yleinen ymmärrys eivät selitä havaintoa; että aikaisemmin esitetyt kysymykset eivät tavoita sitä, mikä menneisyydessä on kiinnostavinta; että emme tiedä vastausta tai välttämättä edes kysymystä.

Miksi Pohjanmaalla rakennettiin järjestelmällisesti vinoja seiniä? Näin kysyy Helsingin yliopiston väitöskirjatutkija Matti Mäkelä liuhaseinäisen hirsirakentamisen perinnettä käsittelevässä artikkelissaan. Hirsirakentamisen teknologia on siirtynyt kokemuksen ja suullisen tiedon mukana paikallisesti rakennusmestarilta toiselle, minkä takia kirjallisia lähteitä on vähän. Kuten Mäkelä osoittaa artikkelissaan, säilyneet kirjalliset lähteet eivät yksin selitä syitä liuhaseinäisten asuinrakennusten yleistymiseen. Sen sijaan tutkija etsii vastauksia yhdistelemällä muistitietoa säilyneiden rakennusten analyysiin. Selviää, että liuhaseinäisellä hirsirakentamisella on ollut useita rakennusteknisiä funktioita esteettisten arvojen lisäksi. Artikkeli on hyvä esimerkki tekniikan historian tutkimusperinteestä, jossa materiaaliset artefaktit auttavat vastaamaan tutkimuskysymyksiin, joita ei pelkkien kirjallisten lähteiden perusteella osattaisi edes kysyä. Talojen hirret muistavat sen, mitä ihmiset ovat unohtaneet.

Tiina Männistö-Funkin tutkimusartikkeli "Miten epäonnistumisesta kerrotaan?” lähestyy puolestaan 1800-luvun puhesyntetisaattoreiden historiaa uudesta näkökulmasta. Kiinnostavaa ei ole niinkään, miten Joseph Faberin ihmishahmoinen Euphonia-kone tai Thomas Alva Edisonin fonografinuket toimivat, vaan se, miten ne eivät toimineet ja miten epäonnistumisesta kommunikoitiin. Tekniikan historia hahmotetaan niin vahvasti uraa uurtaneiden keksijöiden, vallankumouksellisten innovaatioiden ja suurten onnistumisten kautta, että epäonnistumiset unohtuvat helposti. Kuitenkin, kuten Männistö-Funk osoittaa kiehtovien tapausesimerkkien kautta, epäonnistumiset ovat olennainen osa tekniikan historiaa.

Suomen ainoana tekniikan historiaan keskittyvänä julkaisuna, vertaisarvioidut artikkelit muodostavat Tekniikan Waiheita -lehden akateemisen selkärangan. Vuodesta toiseen luettuimpien artikkelien joukkoon kuuluu kuitenkin myös laaja joukko ei-vertaisarvioituja katsausartikkeleita, jotka käsittelevät tekniikan historian monia puolia. Vuoden 2021 toisessa numerossa katsauksia on laaja ja monipuolinen joukko.

"Engineering an industrial city. 125 years of Tampere Technical Society" perustuu Petri Pajun ja Katariina Maurasen vuonna 2018 julkaisemaan historiaan Tampereen teknillisestä seurasta. Englanninkielinen katsaus tiivistää laajan kirjan keskeisimmän sisällön ja avaa suomalaisen teknillisen seuraelämän historiaa myös kansainvälisille lukijoille.

Musiikin historiaan perehtyneen tutkija Tuire Ranta-Meyerin artikkeli saksalaisen fysiikan nobelistin Werner Heisenbergin Suomen matkasta paljastaa kiinnostavalla tavalla aikaisemmin tuntemattoman yhteyden säveltäjä Erkki Melartinin ja Heisenbergin välillä ja valottaa uudesta näkökulmasta ydinfyysikon nuoruusvuosien elämää ja ajatuksia.

Eero Hyvösen laaja katsaus "Sammon taontaa" on tarpeellinen selvitys suomenkielisen digitaaliseen humanismiin läheisesti liittyvistä semanttisen laskennan kehityshankkeista. Digitaalinen humanismi mahdollistaa uudenlaiset historiantutkimuksen metodit ja ennennäkemättömän suurten aineistokokonaisuuksien hyödyntämisen. Suurten odotusten ja lupausten täyttäminen vaatii aitoa tieteidenvälisyyttä ja avointa keskustelu tietotekniikan ja historian ammattilaisten välillä. 
Joulukuussa 2020 Jyväskylän taloushistorian oppiaineessa väitelleen Jouko Wacklinin lektio monialaisen Tampella-yhtiön johtamisesta tiivistää englanninkielisen väitöskirjan Suomen kielelle ja avaa uusinta suomalaista teollisuushistoriaa myös Tekniikan Waiheita -lehden lukijoille.

Numeron viimeistelee kolme kirjallisuusarviota ja esittelyä. Ilkka Mäntyvaaran arvio Sakari Aallon viime vuonna ilmestyneestä teoksesta Hissikuilun partaalta - tarkastajan muistelmat, esittelee asiantuntijan silmin suomalaisten hissihistoriaa. Kaisa Kyläkoski arvioi vuoden 2020 lopulla avoimesti Helsinkin University Pressin julkaiseman digitaalisen historiantutkimuksen kokoelmateoksesta, Digital Histories: Emergent Approaches within the New Digital History (toimittaneet Mats Fridlund, Mila Oiva \& Petri Paju). Veijo Kauppisen kirjoitus Filatelisti-lehdestä ei ole perinteinen kirja-arvio, vaan esittelee Filatelisti-lehteä tekniikan historian harrastajan silmin.

Antoisia lukuhetkiä ja hyvää kesää!

\section{Saara Matala \\ Päätoimittaja}

To cite this article: Saara Matala, "Uudet kysymykset" Tekniikan Waiheita 39, no. 2(2021): 4-5. https://doi.org/10.33355/tw.109428

To link to this article: https://dx.doi.org/10.33355/tw.109428 